\title{
THYROXINE DISPLACEMENT FROM SERUM PROTEINS AND DEPRESSION OF SERUM PROTEIN-BOUND IODINE BY CERTAIN DRUGS
}

\author{
By J. WOLFF, M. E. STANDAERT AND J. E. RALL \\ (From the Clinical Endocrinology Branch, National Institute of Arthritis and Metabolic \\ Diseases, National Institutes of Health, Bethesda, Md.)
}

(Submitted for publication February 6, 1961 ; accepted April 6, 1961)

A number of compounds such as 2,4-dinitrophenol, ${ }^{1}$ salicylate, tetrachlorothyronine, and diphenylhydantoin have been shown to lower the protein-bound iodine level of the blood (1-5). In the case of DNP and salicylate, it was concluded that they acted in part via an inhibition of the pitutary TSH mechanism and partly by an accelerated loss of $\mathrm{T}_{4}$ from the circulation $(2,6)$. A likely site of action was, therefore, expected to involve binding of $\mathrm{T}_{4}$ to serum proteins.

The ability of various analogs of thyroxine to bind to proteins of serum has been extensively studied with electrophoretic techniques. At least three serum proteins and perhaps four have been described which bind thyroxine (7). Less direct methods of studying this binding of the thyroid hormones consist of measurement of the "uptake" of triiodothyronine by erythrocytes (8) and the rate of dialysis of $\mathrm{T}_{4}$ through a cellophane membrane (9). By these techniques several compounds have been found that appear to alter the binding of $T_{4}$ to serum proteins when studied by these techniques but if whole serum is used, the effect cannot be localized to specific proteins. Thus it has been suggested from dialysis studies that salicylates and DNP act by inhibiting $\mathrm{T}_{4}$ binding to serum proteins. Electrophoretic studies in barbital buffer of sera containing salicylate failed to show any influence on the distribution of $\mathrm{T}_{4}$ between TBG and albumin, nor was there any change in the $T_{4}$ binding capacity measured under these conditions (2). Since then it has been shown that barbital buffer inhibits $T_{4}$ binding to prealbumin (10) and Ingbar has stated that

\footnotetext{
1 The following abbreviations have been used: $\mathrm{DNP}=$ 2,4-dinitrophenol; $\mathrm{PBI}=$ protein-bound iodine: $\mathrm{T}_{t}=$ thyroxine; $T B G=$ thyroxine-binding globulin of the interalpha zone in paper electrophoresis; TBPA = thyroxinebinding prealbumin $; \mathrm{TCT}=\mathrm{DL}$-tetrachlorothyronine; $\mathrm{TSH}$ $=$ thyroid-stimulating hormone.
}

salicylate could interfere with $\mathrm{T}_{4}$ binding in electrophoretic systems in buffers other than barbital (11). It was therefore desired to examine $T_{4}$ binding in the presence of these four agents in a system where prealbumin binding of $T_{4}$ could be observed. Furthermore, the possible correlation between the effect of inhibition of thyroxine binding to TBPA and to TBG by various drugs with the in vivo effect of these drugs on the PBI was studied.

\section{METHODS}

A single batch of pooled normal human serum obtained from the Baxter Laboratories was used in all the studies. Butanol solutions of thyroxine were evaporated to dryness in vacuo prior to the addition of serum. The mixtures were incubated at $4^{\circ} \mathrm{C}$ for at least 24 hours before use and were kept in the cold until used.

Electrophoresis in $0.12 \mathrm{M}$ ammonium carbonate buffer, $\mathrm{pH} 8.4$, was performed at room temperature on $3.75 \times$ $49 \mathrm{~cm}$ strips of Whatman no. $3 \mathrm{MM}$ filter paper. The edges of the strips were coated with a thin border of paraffin. The strips were saturated with buffer and suspended horizontally between two plastic clamps in a closed system. The strips were equilibrated for at least 1 hour before the serum was applied. The anodal chamber received an excess of buffer solution just before the current was turned on. Thirty $\mu 1$ of serum was added approximately $8 \mathrm{~cm}$ from the anode just before the voltage was applied. In nearly all cases the reverse flow technique was employed (12) with a constant voltage of $80 \mathrm{v}$.

Two types of studies were carried out. In the first, the inhibitor was added to the serum which was then run in reverse flow electrophoresis. In the second, we followed the suggestion of Ingbar (11) that addition of salicylate to the buffer permitted the demonstration of interference in protein-binding of $T_{4}$. Conventional electrophoresis was used in some cases to rule out the presence of unbound $\mathrm{T}_{4}$ in the albumin (origin) area in reverse flow electrophoresis.

After a run of 17 hours the strips were air-dried, scanned on a continuous recording strip counter, and radioautographed on No-Screen X-ray film. Strips were realigned on the film and the radioactive fractions cut 


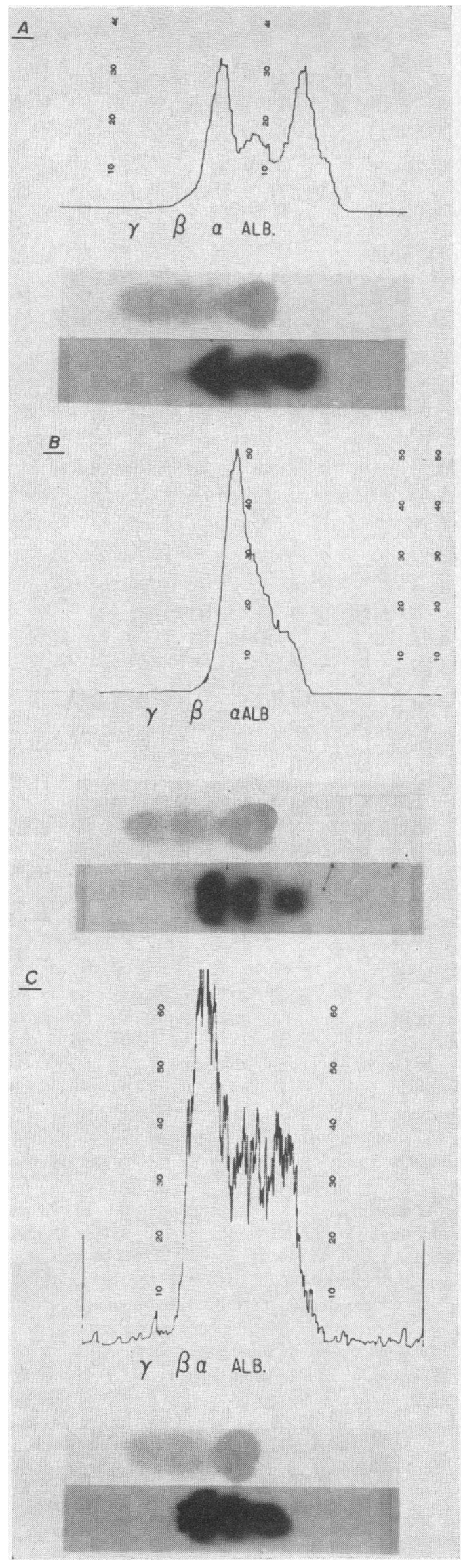

out, using the radioautograph as a guide to their exact location. The filter paper segments were counted in a well scintillation counter. A duplicate strip was stained with bromphenol blue to show the protein location. All results are averages of duplicate or quadruplicate determinations and are reported as fractions of the total thyroxine on each protein fraction.

It is felt that with the reverse flow technique direct counting offered greater accuracy than quantitation of the strip counter recordings. This is especially true in instances where the various agents have displaced all but trace amounts of thyroxine from a binding site. Such quantities are difficult to measure accurately on the strip counter.

For calculations, serum PBI measured by a modification of the Zak procedure (performed by the Boston Medical Laboratories) was assumed to consist entirely of thyroxine. Concentrations of $T_{4}$ listed in Table $I$ have been corrected for the endogenous $T_{4}$ of the serum used. Labeled thyroxine was obtained from Abbott Laboratories and chromatographed before use; when necessary it was purified until better than 90 per cent pure (12). DNP and sodium salicylate were reagent grade and TCT was a generous gift of Dr. Jacob Lerman. When drugs were added directly to the ammonium carbonate buffer, the $\mathrm{pH}$ was adjusted after addition of the drug.

Male guinea pigs of the NIH strain were used. In experiment III (Table II) thyroidectomy was checked by thorough examination of the tracheal region, and all animals suspected of incomplete thyroidectomy were discarded. They were then divided into three groups : an uninjected control group, a thyroxine-injected control group, and a group receiving both thyroxine and TCT. The thyroxine treatment was started 8 days after thyroidectomy and was continued for 12 days. During the last 5 days the third group of guinea pigs received, in addition, subcutaneous injections of TCT. All animals were exsanguinated 3 to 4 hours after the last injection.

\section{RESULTS}

Initial experiments, in which salicylate or DNP was added to the serum before electrophoresis, showed that both these agents tended to displace $\mathrm{T}_{4}$ from TBPA onto TBG. However, experiments in which these agents were added to the buffer gave more reproducible results, and most of the studies presented here will deal with the latter technique.

Fig. 1. THE EFFECT OF 2,4-DINITROPHENOL ON THE ELECTROPHORETIC DISTRIBUTION OF RADIOACTIVE THYROXINE $(0.28 \mu \mathrm{G}$ PER ML OR $0.36 \mu \mathrm{M})$ IN HUMAN SERUM. In this and succeeding figures a record of the radioactivity is above the stained paper strip and a radioautograph of the paper strip is below it. A) Control serum; B) $1 \times$ $10^{-4} \mathrm{M}$ dinitrophenol in the buffer; C) $1 \times 10^{-4} \mathrm{M}$ dinitrophenol added to serum. 
It can be seen from Figures 1 and 2 that the addition of $1 \times 10^{-4} \mathrm{M}$ DNP or $3 \times 10^{-3} \mathrm{M} \mathrm{Na}$ salicylate to human serum containing $3.6 \times 10^{-7} \mathrm{M}$ $\mathrm{T}_{4}$ caused significant displacement of $\mathrm{T}_{4}$ from the prealbumin peak to TBG. This effect was more marked when DNP or salicylate had been added to the $\left(\mathrm{NH}_{4}\right)_{2} \mathrm{CO}_{3}$ buffers (Figures $1 \mathrm{~B}$ and $2 \mathrm{~B}$ as compared with Figures $1 \mathrm{C}$ and $2 \mathrm{C}$ ). At $2.7 \times$ $10^{-7} \mathrm{M} \mathrm{T}_{4}$ (Figure $3 \mathrm{C}$ ) there was practically no radioactivity left in the prealbumin area. At these low $\mathrm{T}_{4}$ concentrations most of the $\mathrm{T}_{4}$ displaced from TBPA was bound by TBG. In the presence of higher amounts of $T_{4}$, the TBG became saturated and the displaced $T_{4}$ was bound to albumin (see Table I). That there was no displacement from albumin was ascertained in studies with standard paper electrophoresis in which albumin is permitted to migrate from the origin. Thyroxine stayed with the albumin and no radioactivity was found at the origin. Displacement of $T_{4}$ from prealbumin as a function of DNP or salicylate concentration is also demonstrated in Table I. Displacement by salicylate could still be demonstrated at $3 \times 10^{-4} \mathrm{M}$, a level easily attained during salicylate therapy $(4.1 \mathrm{mg}$ per $100 \mathrm{ml})$, and was marked at 1 to $3 \times 10^{-3} \mathrm{M}$ levels which have been shown to be accompanied by lowering of the PBI (2).

TCT also could displace $\mathrm{T}_{4}$ from serum proteins, in this case from TBG (Figures $3 \mathrm{~A}$ and $3 \mathrm{~B}$ ). Some displacement of $\mathrm{T}_{4}$ from TBG can be observed at TCT levels as low as $10^{-7} \mathrm{M}$. The displacement can also be demonstrated when the compound is added directly to serum. Comparison of Figures $3 \mathrm{~B}$ and $3 \mathrm{C}$ reveals the striking difference between TCT and salicylate in the electrophoretic distribution of $T_{4}$. In contrast to salicylate and $\mathrm{DNP}, \mathrm{T}_{4}$ displacement is from TBG. At low levels of TCT, the $T_{4}$ that is not bound to TBG is found to be associated with TBPA. At very high levels of TCT there is also inhibition of binding of $\mathrm{T}_{4}$ to TBPA, and the thyroxine thus displaced appears on albumin (Table $\mathrm{I}$ ).

In view of the potent $\mathrm{T}_{4}$ displacing action of TCT, it was important to establish that this com-

Fig. 2. The effect of SAlicylate on the electroPHORETIC DISTRIBUTION OF RADIOACTIVE THYROXINE ( 0.28 $\mu$ G PER ML OR $0.36 \mu \mathrm{M}$ ) IN HUMAN SERUM. A) Control serum ; B) $3 \times 10^{-3} \mathrm{M}$ salicylate in the buffer ; C) $3 \times 10^{-3} \mathrm{M}$ salicylate added to serum.

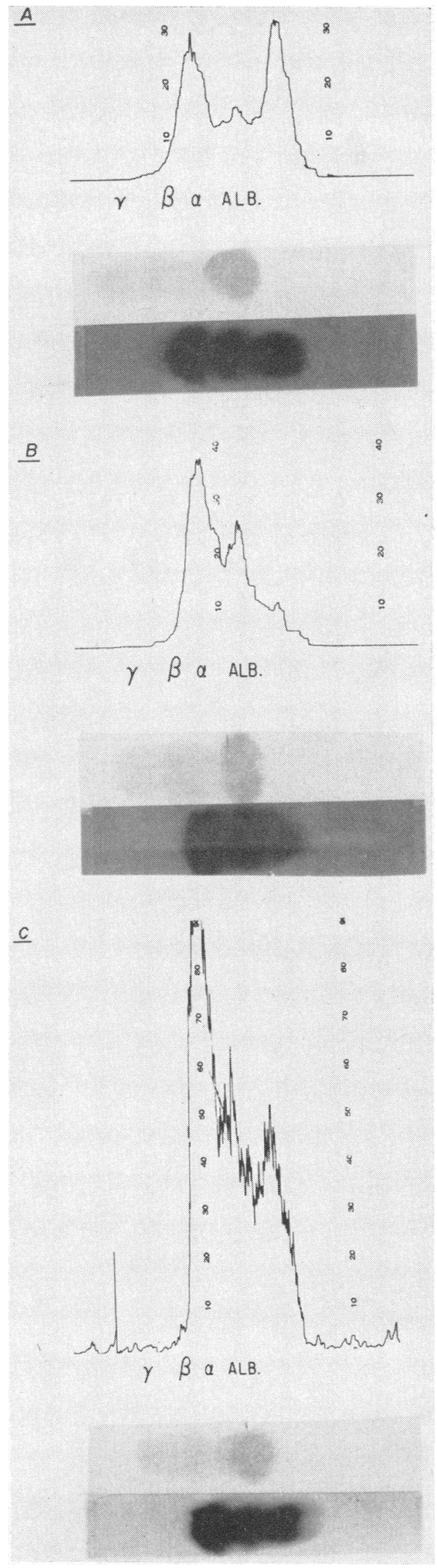




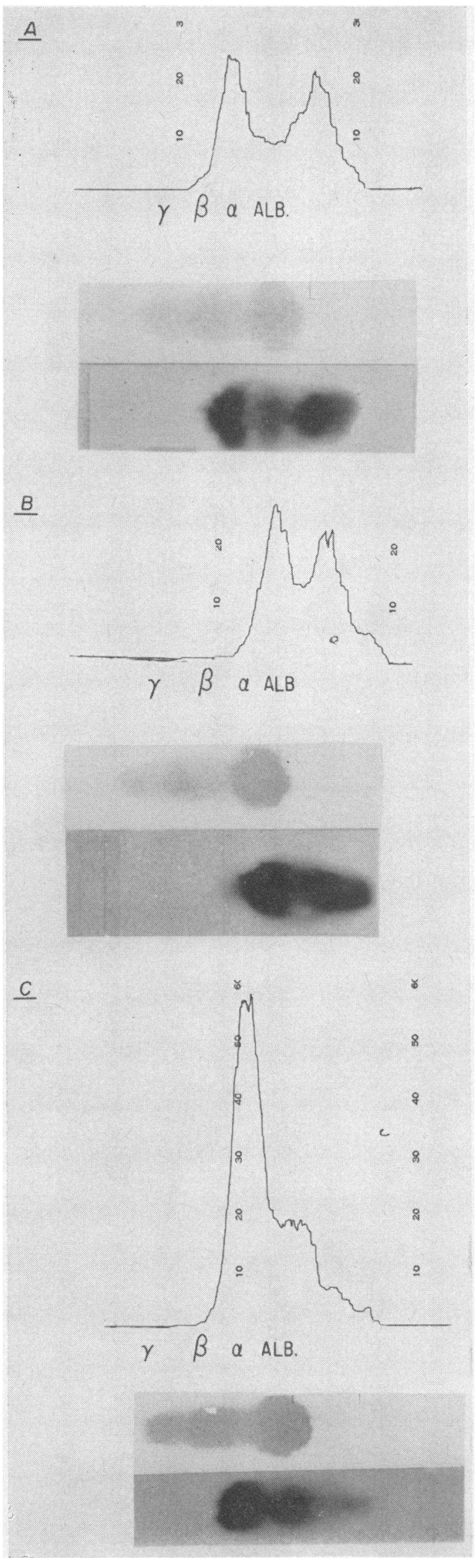

pound could, in fact, lower the PBI when administered to the intact animal since previous observations were not unequivocal $(3,4)$. Although we were able to demonstrate such an effect in rats, the results with guinea pigs were more dramatic and are listed in Table II. A 30 to 35 per cent depression in the PBI could be demonstrated, albeit at rather large doses of TCT. Since this $\mathrm{T}_{4}$ analog does have very weak thyromimetic activity, it seemed important to rule out an indirect effect of TCT, e.g., via the pituitary TSH mechanism. For this reason thyroidectomized guinea pigs on constant doses of $T_{4}$ were utilized. It can be seen that under these conditions TCT lowered the PBI by nearly 50 per cent despite the very high initial PBI level. A similar PBI depression in athyreotic subjects receiving replacement therapy has been reported after DNP treatment in man (13) and after salicylate treatment in rats (14).

Oppenheimer, Fisher, Nelson and Jailer have recently shown that patients chronically treated with diphenylhydantoin show depressed values of PBI and have suggested that this might have resulted from $\mathrm{T}_{4}$ displacement from one of the thyroxine-binding proteins (5). This proved to be the case (see Table I), and at drug concentrations that obtain clinically (15) there was marked displacement of $\mathrm{T}_{4}$ from $\mathrm{TBG}$ to prealbumin. It may also be noted that in the presence of a constant amount of diphenylhydantoin, increasing concentrations of thyroxine result in increasing amounts of $\mathrm{T}_{4}$ bound to TBG. With $10^{-4} \mathrm{M}$ diphenylhydantoin, the amount of $T_{4}$ bound to TBG increased from $0.03 \mu \mathrm{g}$ per $\mathrm{ml}$ at $\mathrm{T}_{4}$ concentration of $0.07 \mu \mathrm{g}$ per $\mathrm{ml}$ to $0.065 \mu \mathrm{g}$ per $\mathrm{ml}$ at a $\mathrm{T}_{4}$ concentration of $0.28 \mu \mathrm{g}$ per $\mathrm{ml}$, and at the highest $\mathrm{T}_{4}$ concentration to $0.15 \mu \mathrm{g}$ per $\mathrm{ml}$. This would be expected when two compounds compete for the same site. Similar considerations apply to the other compounds studied. Even at the highest level of diphenylhydantoin (we were limited by the solubility at this $\mathrm{pH}$ ) there was no displacement from prealbumin, in marked contrast to the results obtained with TCT (Table I). This may

Fig. 3. COMParison OF THE DISPlacement OF RADioACTIVE THYROXINE $(0.15 \mu \mathrm{G}$ PER ML OR $0.27 \mu \mathrm{M})$ FROM HUMAN SERUM PROTEINS PRODUCED BY DL-TETRACHLOROTHYRonine and SALicylate. A) Control serum; B) $3 \times$ $10^{-6} \mathrm{M}$ tetrachlorothyronine in the buffer; C) $3 \times 10^{-3} \mathrm{M}$ salicylate in the buffer. 
TABLE I

The distribution (in per cent) of thyroxine on serum protein fractions as a function of the concentration of various displacing agents

\begin{tabular}{|c|c|c|c|c|c|c|c|c|c|c|c|c|}
\hline \multirow{2}{*}{$\begin{array}{l}\text { Agent (molarity } \\
\text { in buffer) }\end{array}$} & \multicolumn{3}{|c|}{$0.15 \mu \mathrm{g} \mathrm{T}_{4} / \mathrm{ml}(0.19 \mu \mathrm{M})$} & \multicolumn{3}{|c|}{$0.28 \mu \mathrm{g} \mathrm{T}_{4} / \mathrm{ml}(0.36 \mu \mathrm{M})$} & \multicolumn{3}{|c|}{$1.54 \mu \mathrm{g} \mathrm{T}_{4} / \mathrm{ml}(2.0 \mu \mathrm{M})$} & \multicolumn{3}{|c|}{$2.08 \mu \mathrm{g} \mathrm{T} / \mathrm{ml}(2.7 \mu \mathrm{M})$} \\
\hline & TBG & $A$ & $\mathrm{PA}[12] \dagger$ & TBG & $A$ & $\operatorname{PA}[11]$ & TBG & $\mathrm{A}$ & $\mathrm{PA}[5]$ & TBG & $\mathrm{A}$ & PA[5] \\
\hline $\begin{array}{l}\text { Control } \\
\pm \mathrm{SD}\end{array}$ & $\begin{aligned} & 38 \\
\pm & 2.4\end{aligned}$ & $\begin{array}{l}20 \\
\pm 1.2\end{array}$ & $\begin{aligned} & 43 \\
\pm & 1.1\end{aligned}$ & $\begin{array}{l}38 \\
\pm \quad 4.6\end{array}$ & $\begin{array}{l}25 \\
\pm 2.2\end{array}$ & $\begin{array}{l}37 \\
\pm 5.7\end{array}$ & $\begin{array}{l}13 \\
\pm 1.0\end{array}$ & $\begin{array}{l}32 \\
\pm 1.3\end{array}$ & $\begin{array}{c}55 \\
\pm 1.7\end{array}$ & $\begin{array}{l}15 \\
\pm 1.2\end{array}$ & $\begin{array}{l}37 \\
\pm 8.6\end{array}$ & $\begin{array}{l}48 \\
\pm 9.4\end{array}$ \\
\hline $\begin{array}{r}\text { Salicylate } \\
3 \times 10^{-4} \\
1 \times 10^{-3} \\
3 \times 10^{-3}\end{array}$ & 61 & 30 & 9 & $\begin{array}{l}52 \\
61 \\
71\end{array}$ & $\begin{array}{l}24 \\
27 \\
25\end{array}$ & $\begin{array}{r}24 \\
12 \\
5\end{array}$ & & & & $\begin{array}{l}18 \\
21\end{array}$ & $\begin{array}{l}35 \\
59\end{array}$ & $\begin{array}{l}47 \\
20\end{array}$ \\
\hline $\begin{array}{l}\text { 2,4-Dinitrophenol } \\
1 \times 10^{-5} \\
3 \times 10^{-5} \\
1 \times 10^{-4} \\
3 \times 10^{-4}\end{array}$ & $\begin{array}{l}42 \\
55 \\
63\end{array}$ & $\begin{array}{l}17 \\
32 \\
32\end{array}$ & $\begin{array}{r}42 \\
13 \\
5\end{array}$ & $\begin{array}{l}39 \\
56\end{array}$ & $\begin{array}{l}25 \\
28\end{array}$ & $\begin{array}{l}36 \\
16\end{array}$ & 15 & 74 & 11 & $\begin{array}{l}13 \\
11\end{array}$ & $\begin{array}{l}39 \\
54\end{array}$ & $\begin{array}{l}48 \\
35\end{array}$ \\
\hline $\begin{array}{l}\text { Tetrachlorothyronine } \\
1 \times 10^{-7} \\
3 \times 10^{-7} \\
1 \times 10^{-6} \\
3 \times 10^{-6} \\
1 \times 10^{-5}\end{array}$ & $\begin{array}{c}32 \\
20 \\
11 \\
6^{*} \\
4\end{array}$ & $\begin{array}{l}27 \\
36 \\
48 \\
47 \\
69\end{array}$ & $\begin{array}{l}41 \\
44 \\
42 \\
48^{*} \\
26\end{array}$ & $\begin{array}{r}18 \\
14 \\
5\end{array}$ & $\begin{array}{l}41 \\
45 \\
57\end{array}$ & $\begin{array}{l}41 \\
41 \\
38\end{array}$ & 4 & 77 & 19 & & & \\
\hline $\begin{array}{l}\text { 5,5-Diphenylhydantoin } \\
3 \times 10^{-5} \\
1 \times 10^{-4} \\
3 \times 10^{-4} \\
6 \times 10^{-4}\end{array}$ & $\begin{array}{l}21 \\
14 \\
11\end{array}$ & $\begin{array}{l}30 \\
27 \\
29\end{array}$ & $\begin{array}{l}49 \\
59 \\
60\end{array}$ & $\begin{array}{l}29 \\
24 \\
15\end{array}$ & $\begin{array}{l}30 \\
29 \\
30\end{array}$ & $\begin{array}{l}41 \\
47 \\
55\end{array}$ & $\begin{array}{l}10 \\
10\end{array}$ & $\begin{array}{l}31 \\
33\end{array}$ & $\begin{array}{l}59 \\
54\end{array}$ & & & \\
\hline
\end{tabular}

* T 4 concentration for this experiment of $0.19 \mu \mathrm{g}$ per $\mathrm{ml}(0.24 \mu \mathrm{M})$. $\dagger$ Number of determinations at each level in brackets.

imply a difference at the prealbumin binding site, although higher concentrations of the drug might have shown displacement here also. In any case, the present finding, that diphenylhydantoin competes with thyroxine for sites on TBG is a reasonable explanation for the depression of PBI. It is surprising, however, that a compound so unlike the iodothyronines can compete for what appears to be a highly specific binding site on TBG.

\section{DISCUSSION}

There is available a body of evidence which suggests that both the effect and the rate of degrada- tion of thyroxine are functions of the concentration of unbound thyroxine (7). Any factor which decreases protein binding of $\mathrm{T}_{4}$ will, if the total concentration of thyroxine is unchanged, increase the concentration of free thyroxine. Consequently, an important factor in the control of the PBI is the serum concentration of available binding sites for the $T_{4}$. Given a constant output of $T_{4}$ from the thyroid, loss of these sites by competition with a variety of drugs leads inevitably to a depression in the PBI level. This cause for the reduction of the PBI concentration in the circulation must be clearly differentiated from that resulting from a

TABLE II

The effect of tetrachlorothyronine on the PBI of guinea pigs

\begin{tabular}{|c|c|c|c|c|}
\hline Experiment & Treatment & $\begin{array}{c}\text { No. of } \\
\text { guinea } \\
\text { pigs }\end{array}$ & PBI & p* \\
\hline I & $\begin{array}{l}\text { Control } \\
\text { TCT } 0.6 \mathrm{mg} / 100 \mathrm{~g} / \text { day for } 5 \text { days } \dagger\end{array}$ & $\begin{array}{l}5 \\
6\end{array}$ & $\begin{array}{l}3.0 \pm 0.34 \\
2.0 \pm 0.33\end{array}$ & $<0.001$ \\
\hline II & $\begin{array}{l}\text { Control } \\
\text { TCT } 0.4 \mathrm{mg} / 100 \mathrm{~g} / \text { day for } 1.5 \text { days } \dagger\end{array}$ & $\begin{array}{l}6 \\
6\end{array}$ & $\begin{array}{l}2.6 \pm 0.28 \\
1.7 \pm 0.16\end{array}$ & $<0.001$ \\
\hline $\begin{array}{l}\text { III } \\
\text { (All guinea pigs } \\
\text { thyroidectomized) }\end{array}$ & $\begin{array}{l}\mathrm{L}^{-\mathrm{T}_{4}} 6 \mu \mathrm{g} / 100 \mathrm{~g} / \text { day } \ddagger \\
\mathrm{L}-\mathrm{T}_{4} 6 \mu \mathrm{g} / 100 \mathrm{~g} / \text { day } \ddagger \\
\mathrm{TCT} 1.0 \mathrm{mg} / 100 \mathrm{~g} / \text { day } \ddagger \\
\text { Control }\end{array}$ & $\begin{array}{l}6 \\
5 \\
4\end{array}$ & $\begin{aligned} 14.7 & \pm 1.0 \\
7.6 & \pm 0.86 \\
1.1 & \pm 0.29\end{aligned}$ & $\ll 0.001$ \\
\hline
\end{tabular}

${ }^{*} \mathrm{p}$ Values are with respect to the control groups in Experiments I and II and with respect to the $\mathrm{T}_{4}$-injected group in Experiment III.

t In two divided doses per day.

$\ddagger$ The injection schedule is listed in Methods. 
decrease or absence in the thyroxine-binding proteins, as in the case of nephrosis (16), congenital absence of a binding protein (17), or after treatment with methyl testosterone (18). Presumably the homeostatic mechanisms operating to reduce the PBI are similar in all these circumstances.

Inhibition of thyroxine binding to prealbumin has been clearly shown with both salicylate and dinitrophenol. Since there is no evidence that, in the concentrations used, either drug denatures serum proteins, and since there is a good correlation between concentration of drug and degree of inhibition of thyroxine binding, it may be assumed that these drugs compete with thyroxine for binding sites on TBPA. It would appear from the quantities of drug required that the association constant of both of these drugs for TBPA is several orders of magnitude lower than that of thyroxine. Neither of these drugs affects $\mathrm{T}_{4}$ binding to TBG.

It is probable that addition of the drug to the buffer is the better method. If the association constant of drug for TBPA is not high it seems quite likely that if drug is added only to serum, there will be, during electrophoresis, a continual removal of unbound drug. If drug is added to the buffer, a reservoir is provided so that the concentration of drug in the buffer will approach the concentration of free drug. As a result of the uncertainty in the concentration of drug bound to protein, it is not possible to calculate accurately a ratio of binding constants of drug/ $\mathrm{T}_{4}$ for TBPA. Doubt has recently been expressed regarding the physiological importance of TBPA as a binding protein for $\mathrm{T}_{4}$ at $\mathrm{pH} 7.6(19)$. The present data with salicylate and DNP are nevertheless compatible with a significant role for TBPA.

The results with TCT are more easily interpreted because of the apparent high affinity constant of this compound for TBG; although bound less strongly, its binding affinity for TBG probably differs from that of $T_{4}$ by less than an order of magnitude. Since equilibrium is not attained in electrophoresis, a more exact statement of the relative affinities is not possible. At high concentrations TCT also inhibits $\mathrm{T}_{4}$ binding to TBPA. Diphenylhydantoin appears not to have this second action. None of the compounds tested appeared to inhibit $\mathrm{T}_{4}$ binding to albumin. This may be a quantitative phenomenon, since albumin is present in serum at a concentration of $\sim 5 \times 10^{-4}$ $\mathrm{M}$ [with four sites for $\mathrm{T}_{4}(20)$ ] and extremely high concentration of the drugs would be required. Furthermore, it is unlikely that $\mathrm{T}_{4}$ binding to albumin normally plays a significant role in thyroxine metabolism, since the PBI of analbuminemic patients is normal (21). It is highly probable that other drugs will be found that can alter the PBI by this mechanism. It would behoove investigators studying thyroid function during therapy with presumably unrelated drugs to take cognizance of this fact.

It may be concluded, therefore, that a decrease in the number of available binding sites either in TBG or in prealbumin, produced by TCT and diphenylhydantoin or by DNP and salicylate, will (by mass law relations) increase the free $T_{4}$ at the expense of the fraction bound. This will in turn accelerate $\mathrm{T}_{4}$ disappearance from the circulation and ultimately lower the PBI to a new steady state value at which the free $T_{4}$ concentration may be perfectly normal. The in vivo experiments with TCT, which produced a consistent fall in the PBI both in normal guinea pigs and in thyroidectomized, thyroxine-treated animals, offer only indirect support for this hypothesis, since no electrophoretic results on guinea pig sera are reported. Studies of guinea pig sera by the above techniques showed $\mathrm{T}_{4}$ binding only in the albumin area, and $\mathrm{T}_{4}$ displacement from one protein to another within this area would not be detectable.

The above considerations may also be applicable in certain short-term assays of thyromimetic (and antithyroxine) materials. Are such effects, as for example, goiter prevention, due to inherent thyroxine-like activity or do they merely represent an elevation of free $T_{4}$ as a result of thyroxine displacement from one of the serum proteins?

Can decreased $\mathrm{T}_{4}$ binding explain the other phenomena produced by DNP and salicylate? Of the diverse effects of salicylate on thyroid function, loss of binding sites can probably explain the accelerated disappearance of radioactive $T_{4}$ from the circulation $(2,22,23)$. Whether or not the other effects can be similarly explained is not certain at present. The whole problem must be reconsidered from the point of view of intracellular binding proteins and the effect of the drugs upon these. 


\section{SUMMARY}

The binding of thyroxine to human serum proteins has been studied by paper electrophoresis in $\left(\mathrm{NH}_{4}\right)_{2} \mathrm{CO}_{3}$ buffer at $\mathrm{pH} 8.4$.

1. Salicylate and 2,4-dinitrophenol inhibit thyroxine binding to prealbumin, the displaced thyroxine appearing in the thyroxine binding $\alpha$-globulin area.

2. Diphenylhydantoin inhibits thyroxine binding to the thyroxine-binding $\alpha$-globulin, displacing it onto prealbumin.

3. DL-tetrachlorothyronine displaces thyroxine from the thyroxine-binding $\alpha$-globulin, and at high drug concentrations also from prealbumin. Tetrachlorothyronine given in vivo lowers the level of serum protein-bound iodine in intact and in thyroidectomized, thyroxine-treated guinea pigs.

4. It is concluded that loss of binding sites on either of the major thyroxine-binding proteins can explain the lowering of the serum proteinbound iodine produced by the four drugs studied when they are given in vivo.

\section{REFERENCES}

1. Wolff, J., Rubin, L., and Chaikoff, I. L. The influence of 2,4-dinitrophenol on plasma protein-bound iodine. J. Pharmacol. exp. Ther. 1950, 98, 45.

2. Austen, F. K., Rubini, M. E., Meroney, W. H., and Wolff, J. Salicylates and thyroid function. I. Depression of thyroid function. J. clin. Invest. 1958, 37, 1131.

3. Richards, C. E., Brady, R. O., and Riggs, D. S. Thyroid hormone-like properties of tetrabromothyronine and tetrachlorthyronine. J. clin. Endocr. 1949, 9, 1107.

4. Lerman, J., and Harington, C. R. The physiologic activity of tetrabromothyronine and tetrachlorthyronine. J. clin. Endocr. 1949, 9, 1099.

5. Oppenheimer, J. H., Fisher, L. V., Nelson, K. M., and Jailer, J. W. Depression of the serum protein-bound iodine level by diphenylhydantoin. $\mathrm{J}$. clin. Endccr. 1961, 21, 252.

6. Wolff, J., and Austen, F. K. Salicylates and thyroid function. II. The effect on the thyroidpituitary interrelation. J. clin. Invest. 1958, 37, 1144.

7. Robbins, J., and Rall, J. E. Proteins associated with the thyroid hormones. Physiol. Rev. 1960, 40, 415 .

8. Hamolsky, M. W., Ellison, H. E., and Freedberg, A. S. The thyroid hormone-plasma protein com- plex in man. I. Differences in different states of thyroid function. J. clin. Invest. 1957, 36, 1486.

9. Christensen, L. K. Thyroxine-releasing effect of salicylate and of 2,4-dinitrophenol. Nature (Lond.) 1959, 183, 1189.

10. Ingbar, S. H. Pre-albumin: A thyroxine-binding protein of human plasma. Endocrinology 1958, 63, 256.

11. Ingbar, S. H. Communicated at the Meeting of the New York Academy of Sciences, New York, Nov. 1959.

12. Robbins, J. Reverse-flow zone electrophoresis. A method for determining the thyroxine-binding capacity of serum protein. Arch. Biochem. 1956, 63, 461.

13. Castor, C. W., and Beierwaltes, W. Effect of 2,4dinitrophenol on thyroid function in man. J. clin. Endocr. 1956, 16, 1026.

14. Good, B. F., Hetzel, B. S, and Opit, L. J. Effects of salicylate on plasma protein-bound iodine in thyroxine-maintained thyroidectomized rats. J. Endocr. 1960, 21, 231.

15. Kozelka, F. L., and Hine, C. H. Distribution, rate of disappearance and excretion of Dilantin (sodium salt of 5,5-diphenyl-hydantoin) (abstract). J. Fharmacol. exp. Ther. 1940, 69, 292.

16. Robbins, J., Rall, J. E., and Petermann, M. L. Thyroxine-binding by serum and urine proteins in nephrosis. Qualitative aspects. J. clin. Invest. 1957, 36, 1333.

17. Tanaka, S., and Starr, P. A euthyroid man without thyroxine-binding globulin. J. clin. Endocr. 1959, 19, 485.

18. Federman, D. D., Robbins, J., and Rall, J. E. Effects of methyl testosterone on thyroid function, thyroxine metabolism, and thyroxine-binding protein. J. clin. Invest. 1958, 37, 1024.

19. Christensen, L. K., and Litonjua, A. D. Is thyroxine binding by pre-albumin of physiologic importance? J. clin. Endocr. 1961, 21, 104.

20. Tabachnick, M., and Sterling, K. The binding of thyroxine and its analogues by human serum albumin. Clin. Res. 1960, 8, 379.

21. Beck, G. E., and Dorta, T. Un cas d'analbuminémie. Helv. med. Acta 1959, 26, 764.

22. Goldberg, R. C., Wolff, J., and Greep, R. O. The mechanism of depression of plasma protein-bound iodine by 2,4-dinitrophenol. Endocrinology 1955, 56,560 .

23. Escobar del Rey, F., and Morreale de Escobar, G. Studies on the peripheral disappearance of thyroid hormone. IV. The effect of 2,4-dinitrophenol on the $\mathrm{I}^{182}$ distribution in thyroidectomized, L-thyroxine maintained rats 24 hours after the injection of $\mathrm{I}^{131}$ labeled L-thyroxine. Acta endocr. (Kbh.) 1958, 29, 161. 